\title{
Assisted suicide and assisted voluntary euthanasia: Stransham-Ford High Court case overruled by the Appeal Court - but the door is left open
}

\author{
D J McQuoid-Mason, BComm, LLB, LLM, PhD \\ Centre for Socio-Legal Studies, University of KwaZulu-Natal, Durban
}

Corresponding author: D J McQuoid-Mason (mcquoidm@ukzn.ac.za)

\begin{abstract}
Whether persons wishing to have doctor-assisted suicide or voluntary active euthanasia may make a court application based on their rights in the Constitution has not been answered by the Appeal Court. Therefore, if Parliament does not intervene beforehand, such applications can be made - provided the applicants have legal standing, full arguments are presented regarding local and foreign law, and the application evidence is comprehensive and accurate. The Appeal Court indicated that the question should be answered by Parliament because 'issues engaging profound moral questions beyond the remit of judges to determine, should be decided by the representatives of the people of the country as a whole. However, the Government has not implemented any recommendations on doctor-assisted suicide and voluntary active euthanasia made by the South African Law Commission 20 years ago. The courts may still develop the law on doctor-assisted death, which may take into account developments in medical practice. Furthermore, 'the possibility of a special defence for medical practitioners or carers would arise and have to be explored'.
\end{abstract}

S Afr Med J 2017;107(5):381-382. DOI:10.7196/SAMJ.2017.v107i5.12450

The decision in Stransham-Ford $v$ Minister of Justice and Correctional Services and Others ${ }^{[1]}$ by the North Gauteng High Court held that a terminally ill patient with intractable suffering was entitled to commit suicide with the assistance of his doctor, whose conduct would not be unlawful. The evidence was that the applicant was a highly qualified lawyer with terminal stage 4 cancer and had tried several traditional and other forms of medication, including palliative care, without alleviating his suffering. He was fully mentally competent and had only a few weeks left to live. The application was heard on 29 April 2015, and two hours before the judge was due to make his order, Mr Stransham-Ford 'died of natural causes'. At this time, neither the judge nor Mr Stransham-Ford's lawyers knew that he had died. The judge gave his reasons for his judgment on 4 May 2015, knowing of the applicant's death, but not recalling his order as he could have done in terms of the Uniform Rules of Court. ${ }^{[2]}$

In Minister of Justice and Correctional Services and Others $v$ Estate Late Stransham-Ford and Others, ${ }^{[2]}$ the Appeal Court overruled the decision of the court below on three grounds: (i) when Mr StranshamFord died 'his cause of action ceased to exist'; (ii) there was 'no full and proper examination' of the current local and international legal position in the light of the Constitution; and (iii) the order was based on 'an incorrect and restricted factual basis'. However, the Appeal Court left the door open by concluding that assisted suicide is not 'in all circumstances unlawful. ${ }^{[2]}$ A similar application may therefore still be made to the courts, based on proper facts and a full analysis of local and international law in the light of the Constitution.

\section{Death of Mr Stransham-Ford}

The Appeal Court held that the death of Mr Stransham-Ford after the arguments had been heard by the judge, but before the judge gave his order, meant that the 'his cause of action ceased to exist..[2] This was because Mr Stransham-Ford's application 'concerned only his personal situation in seeking relief to enable him to die.' Once he died, therefore, 'no further purpose could be served by granting that relief'.
High Court judges cannot 'make orders on causes of action that have been extinguished, merely because they think that their decisions will have broader societal implications. ${ }^{[2]}$ Had the applicant brought the action in the 'general public interest or as a member of a group or class of persons', different allegations would have to have been made and other potentially interested parties would have to have been cited ${ }^{[2]}$ on which basis the case might have proceeded.

\section{No full and proper examination of} local and internationall law

The Appeal Court's second reason for overruling the decision of the court was that 'there was no full and proper examination of the present state of our law in this difficult area, in the light of authority, both local and international, and the constitutional injunctions in relation to the interpretation of the Bill of Rights and the development of the common law. ${ }^{[2]}$ Suicide and attempted suicide are not crimes; patients are entitled to refuse medical treatment (which does not constitute suicide), and in 'double-effect' situations the conduct of doctors is not unlawful where the doctor knows that 'palliative treatment for pain ... will have the effect of hastening the patient's death. ${ }^{\text {[2] }}$

After analysing the South African cases, the Appeal Court held that the main authority cited in the court ${ }^{[3]}$ did not indicate 'that a criminal offence is committed whenever a person encourages, helps or encourages someone to commit suicide or to attempt to do so. ${ }^{[2]}$ Furthermore, each case must be decided on its merits and the principles governing assisted suicide 'should be applied and adapted to the present day.[] This was particularly so as the 'background would be markedly different, given changes in medical circumstances in the nearly 50 years that have passed since the judgment was given. ${ }^{[2]}$ Any development of the common law would have to decide whether to take a different view of causation, intention or unlawfulness. 'The possibility of a special defence for medical practitioners or carers would arise and have to be explored. ${ }^{[2]}$ Without 
dealing with these issues, the question of whether the constitutional rights of persons in Mr Stransham-Ford's position had been violated could not be considered.

The Court listed the kinds of issues that must be addressed when considering the constitutional guarantees in the Bill of Rights, such as: (i) whether 'the right to life includes a right to die', or does it mean that active voluntary euthanasia must be criminalised; (ii) whether the right to dignity includes 'a right to die when and in the manner we choose'; (iii) whether 'the rights of patients warrant a change in existing criminal law as it affects doctors; (iv) whether the right to healthcare includes 'the provision and possible administration of lethal agents, or does it by necessary implication exclude this'; and $(v)$ what the implications for palliative care are if 'a person's dignity is infringed by their inability to terminate their own life or have it terminated. ${ }^{[2]}$

In terms of the development of foreign law regarding doctorassisted suicide, the Appeal Court found that while a minority of countries allowed it, their mechanisms for doing so varied. Only in two US lower court cases and one Canadian Supreme Court case have the courts found that a constitutional right was unjustifiably infringed by prohibiting doctor-assisted death and doctor-assisted suicide. ${ }^{[2]}$ However, the Appeal Court's decision implies that these issues should be fully canvassed in a future case where the applicant has legal standing and the case is based on correct and relevant facts.

\section{Court order based on incorrect and restricted facts}

The Appeal Court also found that all the available evidence had not been properly placed before the court, and that a true picture of $\mathrm{Mr}$ Stransham-Ford's position and condition was not given. The evidence of a doctor who treated him was that on 20 April 2015 (nine days before the court application), Mr Stransham-Ford had indicated to his former wife that he was concerned about whether he could change his mind about consenting to doctor-assisted death. ${ }^{[2]}$ Furthermore, by 28 April 2015 (the day before the application), he had lapsed into a coma. ${ }^{[2]}$ When he died - contrary to the fears expressed in his court application - he was provided with palliative care at his ex-wife's home that managed his symptoms 'effectively enough for him to be able to die in a homely atmosphere surrounded by family and friends who cared for him. ${ }^{[2]}$ The judge was unaware of any of these changes in Mr Stransham-Ford's condition that might have 'render[ed] the whole application unnecessary.[.[

The Appeal Court indicated that the question of doctor-assisted suicide and voluntary active euthanasia is best answered by Parliament. ${ }^{[2]}$ However, as the Government has not implemented any of the recommendations on doctor-assisted suicide and voluntary active euthanasia made by the South African Law Commission 20 years ago, ${ }^{[4]}$ it is likely that this will have to be done by the courts. The courts to date have not had an opportunity to deal with an appropriate case based on correct and relevant facts to determine whether doctor-assisted suicide and voluntary active euthanasia should be allowed in South African law.

Acknowledgements. None.

Author contributions. Sole author.

Funding. None.

Conflicts of interest. None.

1. Stransham-Ford v Minister of Justice and Correctional Services and Others 2015 (4) SA 50 (GP).

2. Minister of Justice and Correctional Services and Others v Estate Late James Stransham-Ford and Others (531/2015). http://www.saflii.org/za/cases/ZASCA/2016/197.html (accessed 23 February 2017).

3. Ex parte Die Minister van Justisie: In re Grotjohn 1970 (2) SA 355 (A).

4. South African Law Commission. Euthanasia and the Artificial Preservation of Life. Project 86. Pretoria: South African Law Commission, 1997.

Accepted 15 March 2017. 